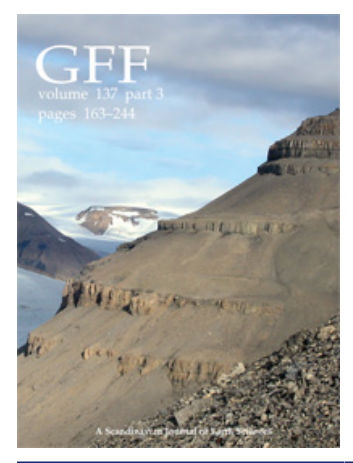

GFF

\title{
Characterization of two new superorders Nautilosiphonata and Calciosiphonata and a new order Cyrtocerinida of the subclass Nautiloidea; siphuncular structure in the Ordovician nautiloid Bathmoceras (Cephalopoda)
}

\section{Harry Mutvei}

To cite this article: Harry Mutvei (2015) Characterization of two new superorders Nautilosiphonata and Calciosiphonata and a new order Cyrtocerinida of the subclass Nautiloidea; siphuncular structure in the Ordovician nautiloid Bathmoceras (Cephalopoda), GFF, 137:3, 164-174, DOI: 10.1080/11035897.2015.1061592

To link to this article: http://dx.doi.org/10.1080/11035897.2015.1061592

曲 Published online: 08 Oct 2015.

Submit your article to this journal

Џ Article views: 23

Q View related articles ¿

View Crossmark data $₫$ 


\title{
Characterization of two new superorders Nautilosiphonata and Calciosiphonata and a new order Cyrtocerinida of the subclass Nautiloidea; siphuncular structure in the Ordovician nautiloid Bathmoceras (Cephalopoda)
}

\section{HARRY MUTVEI}

Mutvei, H., 2015: Characterization of two new superorders Nautilosiphonata and Calciosiphonata and a new order Cyrtocerinida of the subclass Nautiloidea; siphuncular structure in the Ordovician nautiloid Bathmoceras (Cephalopoda). GFF, Vol. 137 (Pt. 1, September), pp. 164-174. (C) Geologiska Föreningen. doi: http://dx.doi. org/10.1080/11035897.2015.1061592.

\begin{abstract}
Based on differences in the siphuncular structures, the subclass Nautiloidea is divided into two new superorders: Nautilosiphonata and Calciosiphonata. The first superorder is characterized by the nautilus-type of connecting rings, and the second superorder by calcified-perforate type of the connecting rings. A new order Cyrtocerinida is erected for the families Bathmoceratidae, Cyrtocerinidae and Eothinoceratidae, previously included in the order Ellesmeroceratida. The siphuncular structure in the Ordovician nautiloid Bathmoceras holmi n. sp. is described. It is characterized by (1) connecting rings that are composed of an outer, calcareous, spherulitic-prismatic layer and an inner, fibrous, chitinous layer, and (2) prominent siphuncular ridges that originate from the inner surfaces of the connecting rings. The structure of the siphuncular ridges in Bathmoceras is compared with that of the actinosiphonate lamellae in the Silurian oncocerid nautiloid Octamerella.
\end{abstract}

Keywords: Palaeozoic nautiloid cephalopods; siphuncle; superorders Nautilosiphonata; Calciosiphonata; order Cyrtocerinida; Bathmoceras

Department of Palaeobiology, Swedish Museum of Natural History, Box 50007, SE-10405 Stockholm, Sweden; harry.mutvei@nrm.se

Manuscript received 8 January 2015. Revised manuscript accepted 9 June 2015.

\section{Introduction}

Recent studies (summarized in Mutvei 2002a, 2002b) show that nautiloids are divided into two groups that have different types of siphuncular structures: (1) the nautilus-type, and (2) the calcified-perforate type. The first type is characterized by connecting rings that each is composed of an outer, calcareous, spherulitic-prismatic layer and an inner, fibrous, chitinous layer that generally is destroyed by diagenesis. In the calcifiedperforate type, the inner fibrous layer of the connecting ring is replaced by a calcareous layer that is perforated by cavities and pore canals. The first group of nautiloids is here placed in a new superorder Nautilosiphonata and the second group of nautiloids in a new superorder Calciosiphonata.

During the Ordovician, nautiloid cephalopods underwent an explosive evolutionary phase and, as a result, numerous new taxa appeared (Kröger \& Landing 2008; Kröger et al. 2009a). One new taxon was Bathmoceras of the family Bathmoceratidae that appeared in the Middle Ordovician. Flower (1964) and Chen \& Teichert (1987) assigned the family Bathmoceratidae to the suborder Cyrtocerinina in the order Ellesmeroceratida. However, the siphuncular structure in cyrtocerinids is much more specialized than that in ellesmerocerids. The cyrtocerinids are therefore placed in a new order Cyrtocerinida.
Holm (1899) was the first to give a correct and detailed description of the shell structure in Bathmoceras sp. from the Middle Ordovician in Sweden. In the present report, the siphuncular structure is described in Bathmoceras holmi $\mathrm{n}$. sp. from the Middle Ordovician of Estonia and it is compared with that in Bathmoceras sp. (Holm 1899) and that in the Silurian oncocerid nautiloid Octamerella (Mutvei 2011, 2013).

\section{Material and methods}

The material studied in the present paper comprises the following specimens.

(1) One well-preserved shell of Bathmoceras (specimen no. Mo. 151247, deposited at the Swedish Museum of Natural History, Department of Palaeobiology, Stockholm), here assigned to the new species $B$. holmi. It was collected by Mikwitz in the $19^{\text {th }}$ century from the uppermost part of the Middle Ordovician Kundan stage at Tallinn, Estonia. It consists of a $10.0 \mathrm{~cm}$ long section of a phragmocone with 30 chambers and a $4.0 \mathrm{~cm}$ long section of a nearly complete body chamber (Fig. 1(A)). It was studied by 


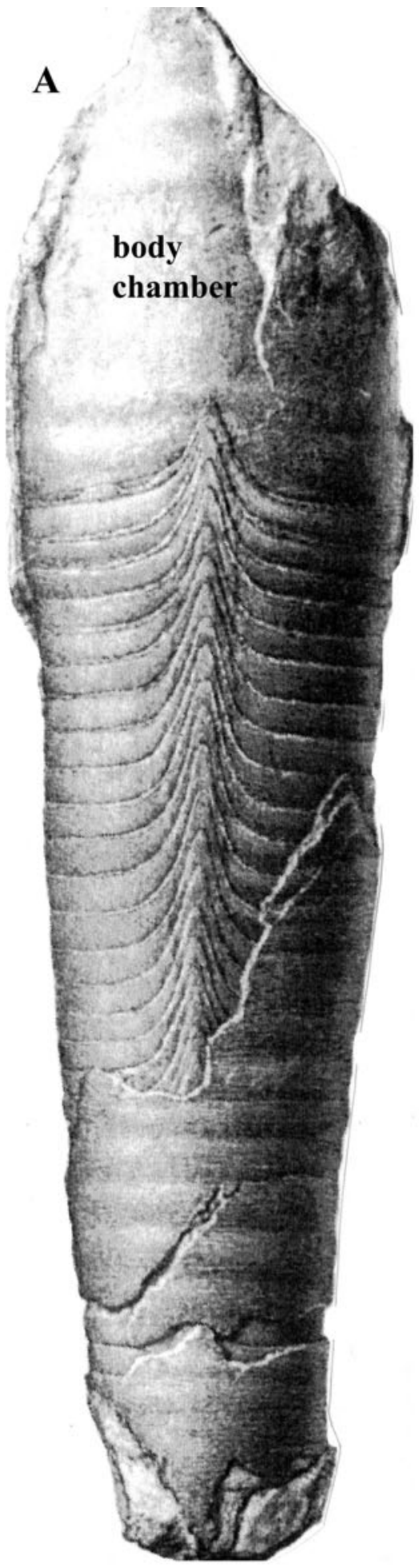

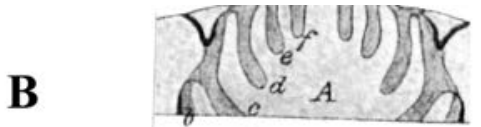

C
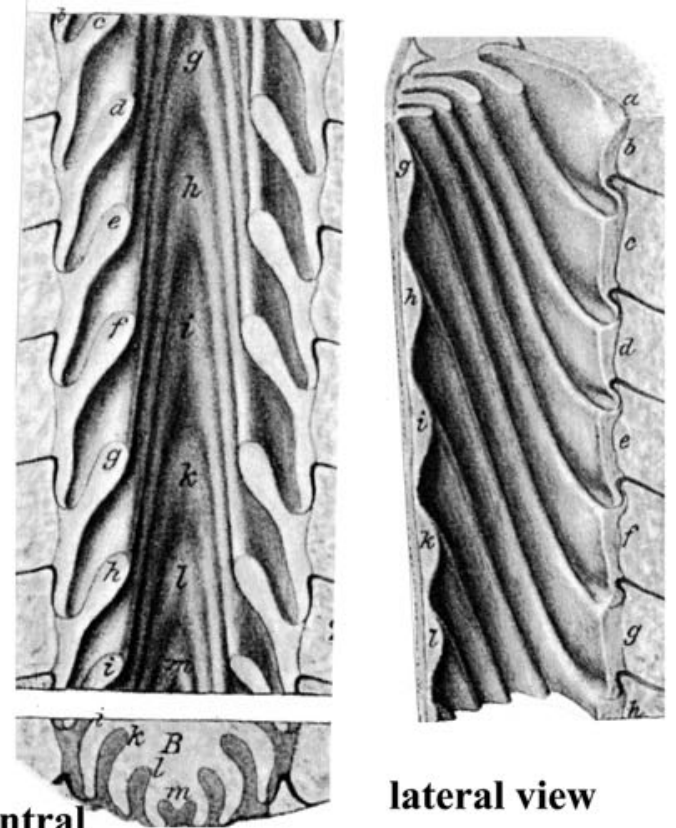

lateral view
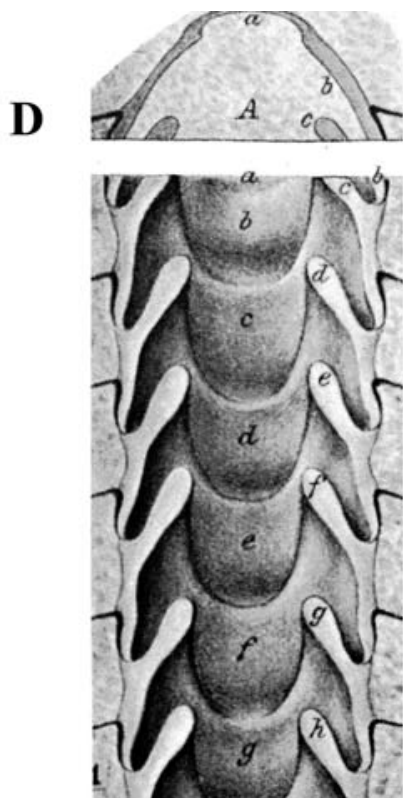
and

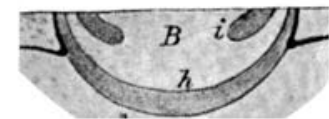

view

F

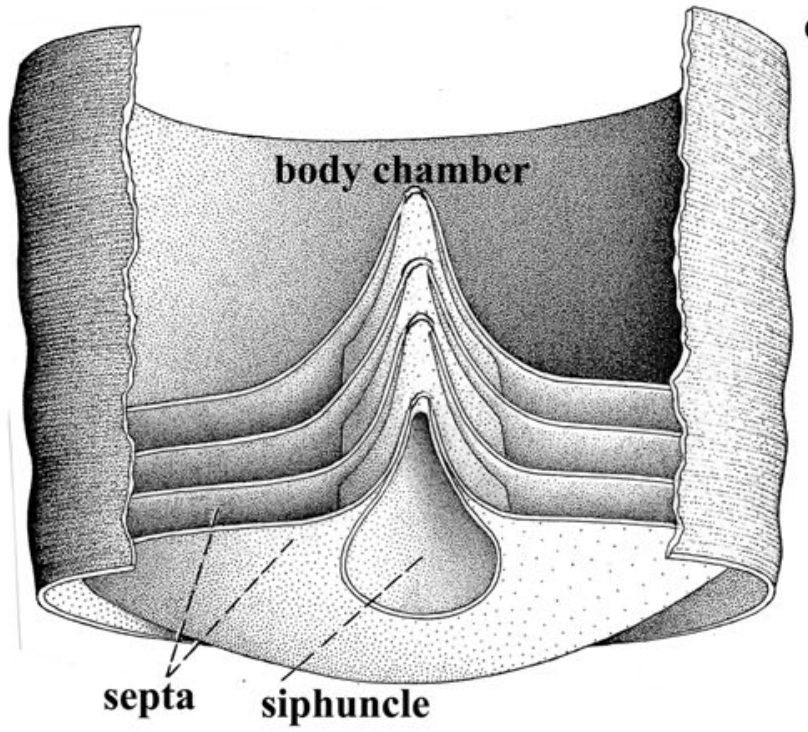

G

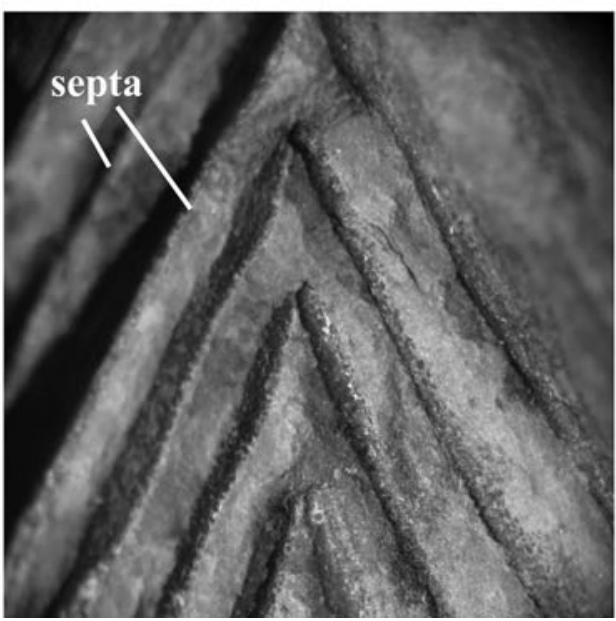


G. Holm who made 20 vertical and transverse sections of the siphuncle and prepared three plates with illustrations that were printed by Holm but never published. The original plates and photographs are stored at the Swedish Museum of Natural History, Stockholm. Five of Holm's original illustrations are selected and included in the present paper (Fig. 1(A)-(E)). These illustrations show the original shape of the specimen before sectioning, and detailed threedimensional reconstruction of the siphuncle. Unfortunately, Holm did not leave any notes or descriptive captions to the plates.

(2) The second studied shell was described by Holm (1899) as Bathmoceras sp. (specimen SGU, Ser. C. no. 179, deposited at the Swedish Geological Survey, Uppsala). It was collected at the boundary between the Hunderumian and Valastean substages of the Middle Ordovician Kundan stage (see Jaanusson \& Mutvei 1982; Mutvei 1996) on the island of Öland, Sweden. It is preserved as a $7.0 \mathrm{~cm}$ long and $3.0 \mathrm{~cm}$ broad section of the ventral side of a phragmocone (Holm 1899, pl. 5). Of this small specimen, Holm cut 25 longitudinal and transverse sections of the siphuncle, several of which are 1.0-2.0 mm thick (Holm 1899, pls. 5-8). It is unknown how Holm was able to cut so many and such thin sections.

(3) The V-shaped ventral sinuses of the suture lines are illustrated in Bathmoceras linnarsoni Angelin \& Lindström (1880, pl. 16, fig. 4, specimen no. Mo. 150046) from the orthocerid limestone, Ordovician, Västergötland, Kinnekulle, Sweden.

(4) The structure of the siphuncular lobes in Bathmoceras is compared with that of the actinosiphonate lamellae in the Silurian oncocerid nautiloids: (a) Octamerella sp. (Mo. 5835, previously illustrated in Mutvei 2011, figs. 3-7) from the Llandoverian Lower Visby mudstone, (b) Octamerella cf. pugil (Mo. 152127, previously illustrated in Mutvei 2011, fig. 2B,C) from the Wenlockian Hemse Beds, Mannagårda, Lyen, and (c) Octamerella cf. pugil (Mo. 15248, previously illustrated in Mutvei 2011, fig. 2A) from an unknown locality, all collected from the Silurian of the island of Gotland, Sweden.

The siphuncular structure was studied in polished sections using a Wild Photomakroskop 400 and a Hitachi S-4300 scanning electron microscope (SEM) at the Swedish Museum of Natural History, Stockholm. Analysis of elemental distribution in the shell was made with an energy dispersive apparatus (EDAX) at the same museum.

\section{Systematic paleontology}

\section{Subclass Nautiloidea}

New superorders Nautilosiphonata and Calciosiphonata There are two basic structural types of siphuncles that have been distinguished in the nautiloids: (1) the nautilus-type and (2) the calcified-perforate type. All hitherto made studies show distinct differences between these two types. Each type has numerous subtypes that characterize different taxonomic groups. Nautiloids with the first type of siphuncles are placed in the new superorder Nautilosiphonata and nautiloids with the second siphuncle-type in the new superorder Calciosiphonata. The two superorders are known as far back as the late Cambrian when they comprised the ellesmerocerid-like nautiloids with the nautilus-type of siphuncles and the plectronocerid nautiloids with the calcified-perforate type of siphuncles (Mutvei et al. 2007).

\section{New superorder Nautilosiphonata}

The septal necks in this suborder are either orthochoanitic, holochoanitic or cyrtochoanitic. The connecting rings are of the nautilus-type and are composed of a calcareous, spheruliticprismatic layer on the outer surface of the septal neck, and an inner, fibrous, chitinous layer that is a non-mineralized continuation of the nacreous layer of the septal neck. The latter layer is typically destroyed by diagenesis. In addition to the Nautilus, this siphuncular-type is present in the orders Nautilida, Tarphycerida, Ellesmerocerida, Discocerida, Oncocerida, new order Cyrtocerinida and probably also in Ascocerida (Mutvei 2002a, 2011, 2013; Mutvei \& Stumbur 1971; Mutvei \& Dunca 2011, Mutvei et al. 2010; Stumbur \& Mutvei 1983; Hewitt \& Stait 1985; Evans \& King 1990; Kröger 2012; Kröger \& Mutvei 2005; Kröger \& Landing 2008; Kröger et al. 2009a, 2009b; Nielsen et al. 2009). The orders Ellesmerocerida, Discosorida, oncocerida and probably also Ascocerida, are closely related and belong to the superorder Multiceratoidea that, in addition to the nautilus-type of the siphuncle, is characterized by short body chamber, more or less constricted aperture at terminal growth stage, and multiple muscle scars at the base of the body chamber. Also Tarphycerida with longer body chamber probably belongs to the Multiceratoidea. The genus Bathmoceras of the order Cyrtocerinida differs from the Multiceratoidea by lack of distinct muscle scars on the annular elevation. However, the annular elevation is broader on the dorsal side than on the ventral side of the body chamber.

\section{New superorder Calciosiphonata}

This superorder comprises the fossil nautiloids that have the calcified-perforate type of connecting rings. The septal necks are orthochoanitic to cyrtochoanitic. As in the Nautilosiphonata, the outer layer of the connecting ring is the spheruliticprismatic layer; the inner layer of the connecting ring is not the fibrous chitinous layer as in the Nautilosiphonta, but instead, there is a calcareous layer that is perforated by numerous larger or smaller cavities and pore canals. The inner layer is a direct, structurally modified, continuation of the nacreous layer of the septal neck. This siphuncular-type is present in the fossil nautiloid orders Plectronocerida, Orthocerida, Actinocerida and probably also in Barrandeocerida (Mutvei 1996, 1998, 2002b,

Fig. 1. B. holmi. A.-E. Printed but unpublished figures of the holotype by G. Holm. A. Specimen no. Mo. 151247, complete shell in ventral view, $\times 2.0$. E. Fragment of the same shell to show the shell surface with annuli and growth lines, $\times 3.0$. B-D. Reconstructions of the shape of the siphuncular ridges on the ventral, lateral and dorsal sides of the siphuncle. F. Reconstruction of the adoral portion of the phragmocone to show oblique directions of the siphuncular segments and septa in ventral view. G. B. linnarssoni Specimen no. Mo. 150046, ventral side of the siphuncle to show the V-shaped sinuses of the suture lines, $\times 2.0$. 
A body chamber

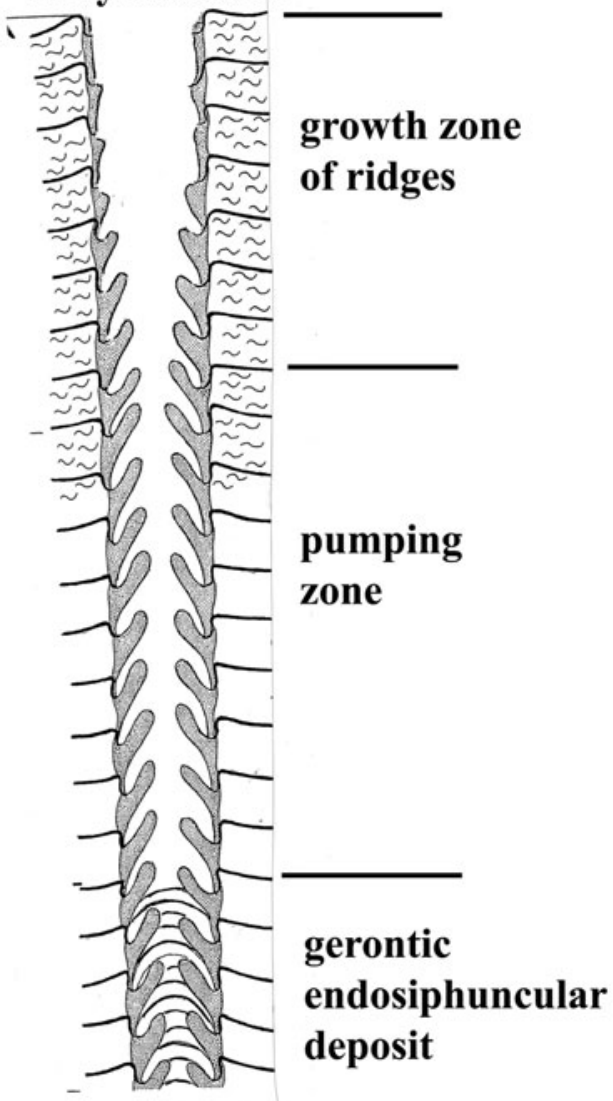

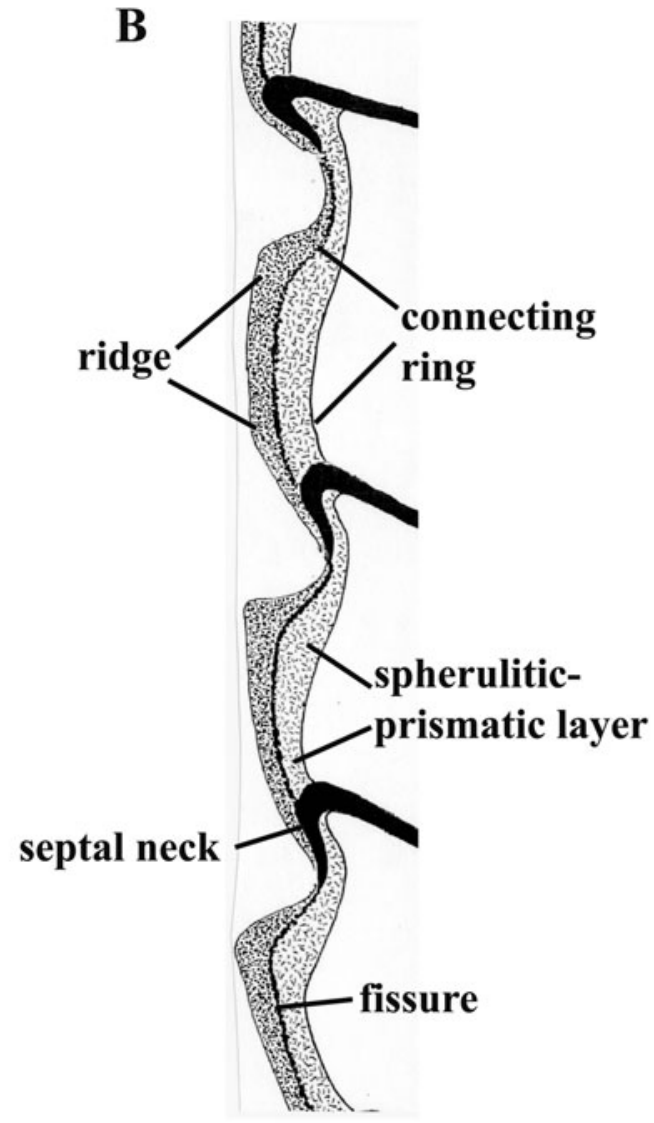

\section{C ventral}

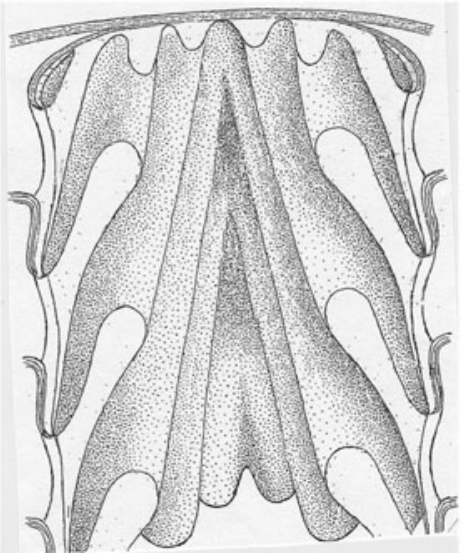

D lateral

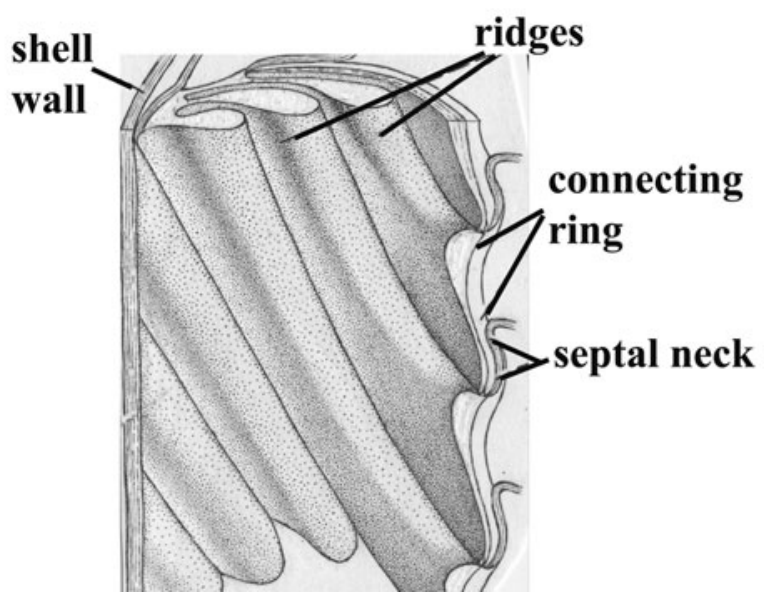

E dorsal

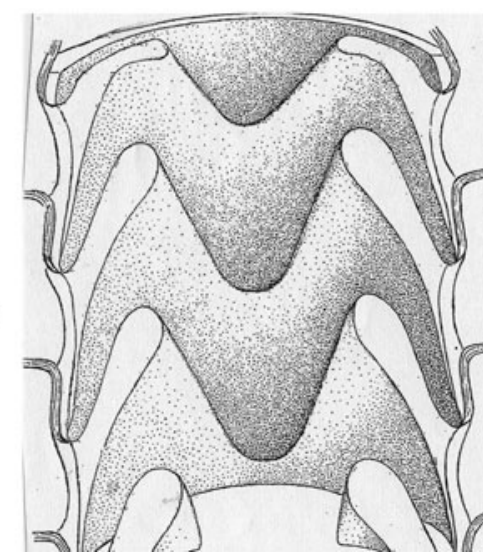

Fig. 2. B. holmi. A. Reconstruction of the siphuncle to show the growth zone, pumping zone and the zone with gerontic endosiphuncular lamellae. B. Schematical median section of the dorsal side of the siphuncular wall. $\mathbf{C}-\mathbf{E}$. Reconstruction of the siphuncle in lateral, ventral and dorsal sides.

2012; Mutvei et al. 2007; Kröger 2004, 2006; Niko \& Sone 2014). The orders Orthocerida and Actinocerida are closely related. The muscle scars in Orthocerida are distinct and situated on the dorsal side of the body chamber, whereas in Actinocerida the annular elevation is indistinct and forms a narrow band around the body chamber without showing muscle scars. In Barrandeocerida, the muscle scars are situated on the lateral sides of the body chamber. The relationship between Orthocerida-Actinocerida and Barrandeocerida is still unclear. 

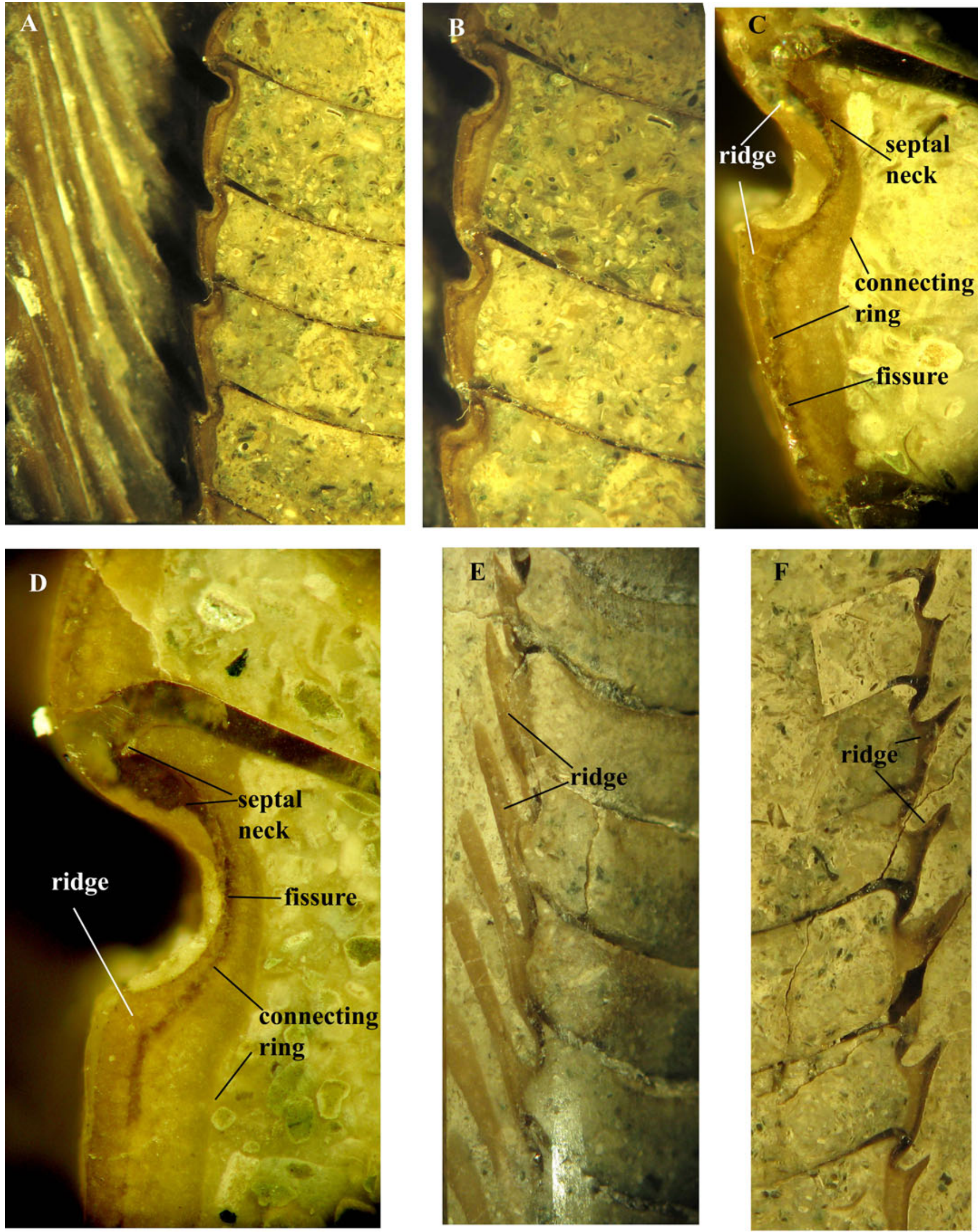

Fig. 3. B. holmi. Specimen no. Mo. 151247. A. Median section of the siphuncle to show the dorsal siphuncular wall and siphuncular ridges, $\times 6.0$. B-D. Details of the dorsal siphuncular wall in higher magnifications; the fissure was probably originally occupied by the inner chitinous layer of the connecting ring, $\mathbf{B}=\times 10, \mathbf{C}, \mathbf{D}=\times 30$. E. F. Growth zone of the siphuncular ridges on the lateral and dorsal sides of the siphuncle, $\times 6.0$. 

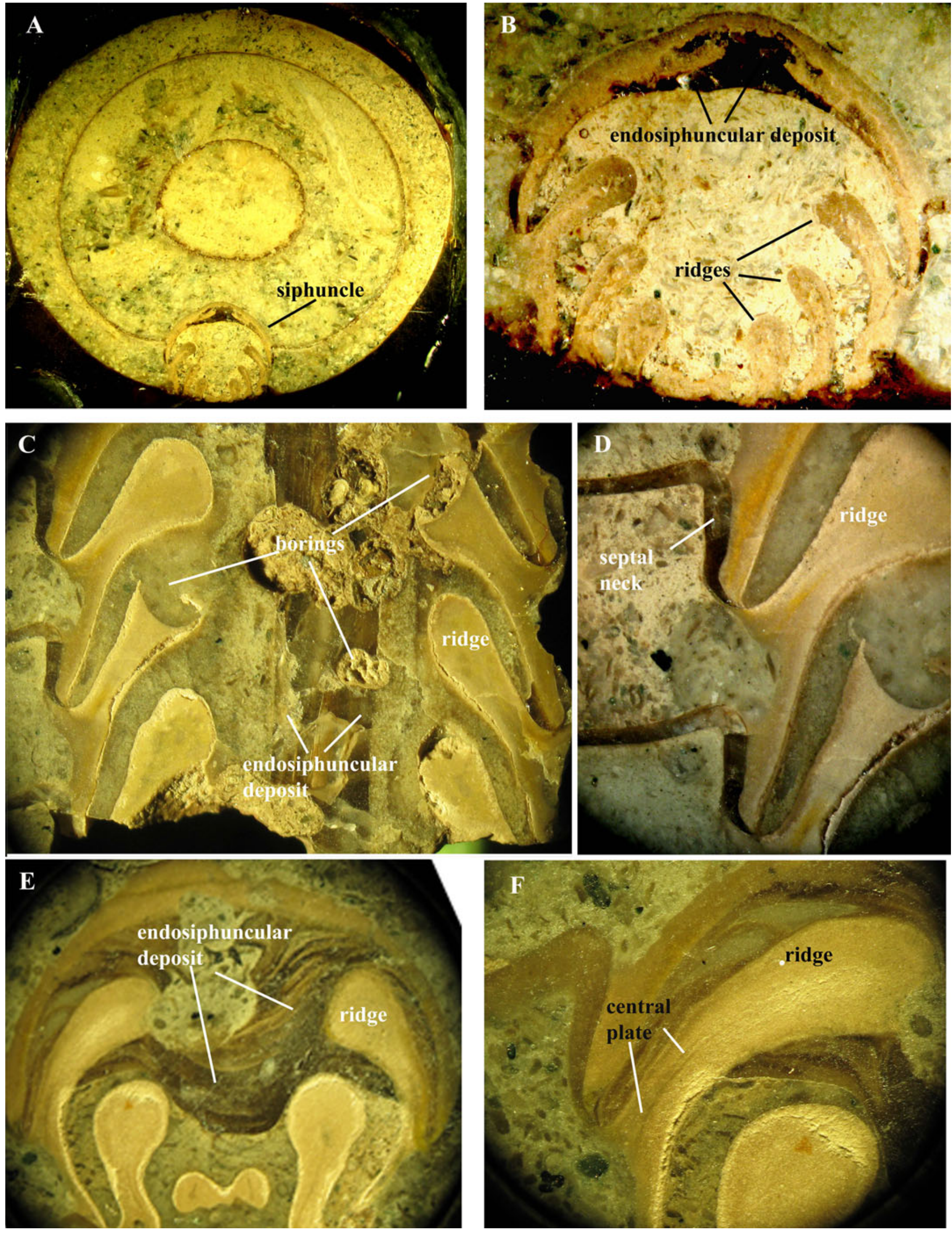


\section{New order Cyrtocerinida}

The genus Bathmoceras Barrande 1865 was placed in the family Bathmoceratidae by Gill (1871). Flower (1964) assigned this family to the suborder Cyrtocerinina that was said to include two additional families: Cyrtocerinidae Flower 1946 and Eothinoceratidae Ulrich et al. (1944). This suborder was said to be characterized by thick connecting rings that have concave outer surfaces (concavosiphonate), and "collars or lobes of various shapes" that extend from the connecting rings into the siphuncular cavity (Chen \& Teichert 1987, p. 157; Cichowolski et al. 2014). The Cyrtocerinina was placed in the order Ellesmeroceratida. At present, there is no reason to remove Bathmoceras from Cyrtocerinina because of high probability that the collars, lobes and siphuncular ridges are homologous. It is also no reason to retain Bathmoceras in the order Ellesmerocerida because of great differences in the siphuncular structures. It is therefore valid to place the suborder Cyrtocerinina in a new order Cyrtocerinida.

Diagnosis. Shell orthoconic to breviconic; siphuncle with large diameter; connecting ring of nautilus-type with concave outer surface; inner siphuncular surface covered by calcareous cones, collars or ridges, each of which was secreted on the inner surface of a connecting ring immediately after a new chamber was completed.

\section{Family Bathmoceratidae}

\section{Bathmoceras holmi $n$. sp}

Figures $1 A-F, 2,3,4 A, B, 6 B$

Holotype. In the Swedish Museum of Natural History, Department of Palaeobiology, specimen no. Mo. 151247.

Type locality and horizon. The holotype was collected by A. Mickwitz at the end of the $19^{\text {th }}$ century at Pinding, the former penalty prison of Tallinn, Estonia (original label by A. Mickwitz: Pinding, Strafgefängniss bei Reval). The stratigraphic horizon is probably the upper part of the Middle Ordovician Kundan stage (Aluojan substage). This horizon is exposed in the adjacent Harku quarry where many, originally aragonitic fossils, including nautiloids, are partially phosphatized and therefore are well preserved (see Mutvei 1996, 1998, 2002a, 2002b).

Material. Only the holotype is known.

Derivation of name. In honor of Gerhard Holm, 1853-1926, Swedish paleontologist who published several excellent studies on fossil nautiloids.

Diagnosis. Medium-sized, slightly depressed, straight shell. The apical angle of the phragmocone is 10 degrees. Low but distinct annuli and fine growth lines ornament the shell surface. The siphuncular ridges are slender in cross-sections. Four to five ridges are exposed in a cross-section of the siphuncle. Bathmoceras sp., described by Holm (1899), differs from $B$. holmi by its much larger size and by the club-like shape of the siphuncular ridges in cross-sections.
Shell. The shell is longiconic. It comprises a $45 \mathrm{~mm}$ long portion of the body chamber, without the apertural region, and a $100 \mathrm{~mm}$ long portion of the phragmocone with about 25 chambers, without the apical portion (Fig. 1(A)). The total length of the shell is estimated to have been slightly more than $200 \mathrm{~mm}$. The phragmocone has an apical angle of about $10^{\circ}$, but the body chamber shows a slight decrease in diameter in the opposite, adoral direction. The shell is slightly depressed in cross-section (Fig. 2(B)). The maximum diameter of the phragmocone is $35 \mathrm{~mm}$, measured at the base of the body chamber.

The shell surface is ornamented by distinct annuli (Fig. 1(A), (E)). About five annuli occur in a distance equal to the shell diameter. The annuli leave low elevations on the surface of the internal mould of the body chamber. On and between the annuli, the shell surface shows fine lamellar growth lines. To judge from the course of the annuli and growth lines, the apertural margin was essentially transverse to the shell axis, without forming sinuses.

Septa and siphuncular segments. The septa are thin and only slightly convex (Fig. 1(E),(F)). They are closely spaced and the height of the chambers is only about $3 \mathrm{~mm}$ each (Fig. 1(F)). Around the siphuncle, the septa bend abruptly and obliquely in the apertural direction (Fig. 1(F)). As a consequence, the siphuncular segments are highly oblique, sloping adorally from the dorsal side to the ventral side. The sutures therefore form extremely high and narrow, $\mathrm{V}$-shaped sinuses on the ventral side (Fig. 1(A), (G)). The height of the ventral sinus is equal to the height of two-three chambers. On the lateral sides, the sutures are practically straight, but form an indistinct, shallow and broad lobe on the dorsal side.

Siphuncle and septal necks. The siphuncle is situated close to the ventral side of the shell wall. In cross-section, the siphuncle is slightly depressed (Fig. 4(A),(B)). Its lateral diameter is equal to one-fourth to one-fifth of the lateral shell diameter. In the median section, the septal necks are orthochoanitic with a slight S-shape (Figs. 1(B)-(D) and 2(A)-(E)). Their shape is best preserved in a specimen of Bathmoceras sp. (Fig. 4(C),(D),(F); Holm 1899, pls. 5, 9:2, 11, 12:1). The distal end of the septal neck forms a sharp edge that is obliquely pointed toward the siphuncular cavity (Fig. 4(C),(D),(F)). In B. holmi, the length of a septal neck is about one-third to one-fourth of the distance between consecutive septa on the dorsal side (Figs. 2(B) and 3 (A)-(D)), whereas in the specimen of Bathmoceras sp. the septal necks are longer, each being about half of the distance between consecutive septa (Fig. 4(C),(D)).

Connecting rings. The connecting rings are of the nautilustype (Mutvei 2002a, 2002b), characterized by the outer spherulitic-prismatic layer and the inner chitinous layer. However, only the outer spherulitic-prismatic layer is preserved in our specimen. This layer is considerably thicker than the corresponding layer in specimens of extant Nautilus (Figs. 2(B) and 3(C),(D)). It originates from the outer surface of the septal neck. As in other fossil nautiloids with the nautilus-type of siphuncle, the inner chitinous layer of the

Fig. 4. B. holmi. Specimen no. Mo. 151247. A. Transverse section of the shell, $\times 3.0$. B. Siphuncle in the same section to show the siphuncular ridges and the gerontic endosiphuncular deposit, $\times 8.0$. Bathmoceras sp. Specimen no. SGU 179. C. Longitudinal section of the shell through lateral sides, $\times$ 8.0. D. Septal necks and siphuncular ridges in higher magnification, $\times 16$. E. Transverse section of the siphuncle; note the gerontic endosiphuncular deposit, $\times 8.0$. F. Siphuncular ridge in the same section in higher magnification to show the central plate, $\times 16$. 

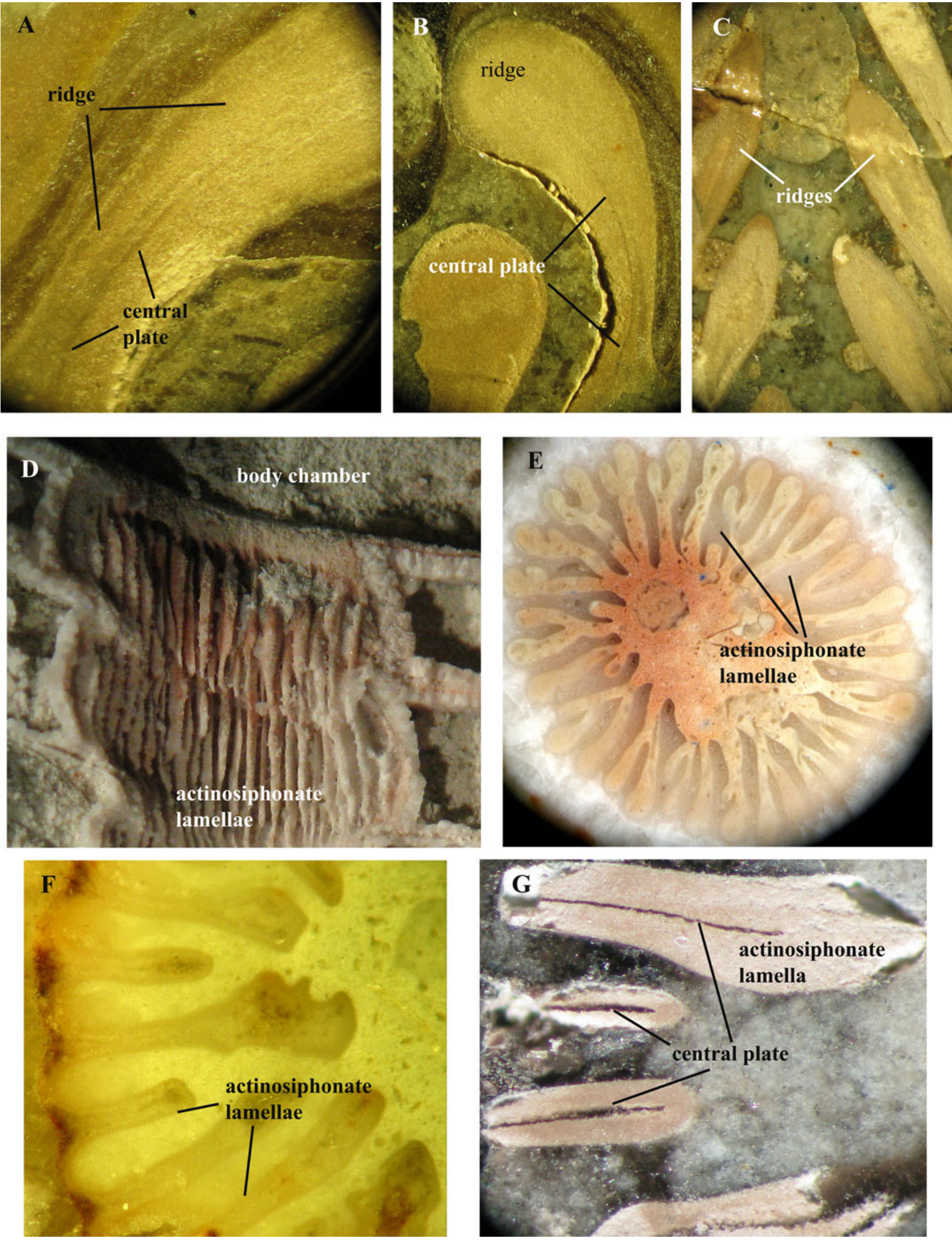
connecting ring has been destroyed during diagenesis, and probably only a narrow fissure between the spheruliticprismatic layer of the connecting ring and the siphuncular ridge is left to mark the place where this layer was attached. The fissure can be observed in four chambers where it extends from the distal end of the septal neck to the preceding septal neck (Fig. 3(C),(D)).

In median sections, the outer surface of the connecting ring is somewhat concave (Figs. 2(B)-(E) and 3(A)-(D)). The siphuncles with concave connecting rings were named concavosiphonate (Flower 1964; Chen \& Teichert 1987). Both in the specimen of $B$. holmi (Fig. 3(E),(F)) and that of Bathmoceras sp. (Fig. 4(C),(D); Holm 1899, pl. 5, fig. 4; pl. 7; pl. 8, fig. 10, 11), the spherulitic-prismatic layer of the connecting rings has been destroyed diagenetically in many chambers leaving a transverse depression along the outer surface of each siphuncular segment.

Siphuncular ridges. The inner surface of the siphuncle shows prominent siphuncular ridges (Figs. 2(B)-(E) and 4(B)). Each ridge originates from the inner surface of the connecting ring and has a spherulitic-prismatic structure. In most connecting rings, the boundary between the rings and the ridges is not distinguishable. Holm (1899) therefore interpreted the siphuncular ridges as parts of the connecting rings. Each siphuncular ridge is low on mid-ventral and mid-dorsal sides of the siphuncle (Figs. 1(C), 2(B),(D) and 3(A) $-(\mathrm{D}),(\mathrm{F}))$, but becomes high and narrow on the lateral sides where it projects obliquely in the adoral direction into the siphuncular cavity (Figs. 1(B),(D), 2(C),(E), 3 (E) and 4(B)). In cross-sections of the siphuncle, five to six ridges are exposed (Fig. 4(B)). Semi-quantitative analyses with EDAX show that the spherulitic-prismatic layer of the ridges contains $50 \% \mathrm{P}, 40 \% \mathrm{Ca}$ and $5 \% \mathrm{Si}$, on the basis of molecular weight.

In SEM preparations, the spherulitic-prismatic layer in the siphuncular ridges shows a diagenetically altered, dense structure. The acicular crystallites in the prisms and spherulites have been coalesced, partially dissolved and can be distinguished only in places (Fig. 6(B)). The original structure of the ridges was similar to the spherulitic-prismatic layer in the actinosiphonate lamellae of the Silurian oncocerid nautiloid Octamerella (Fig. 6(A); Mutvei 2011, Figs. 6 and 7A-D). As in the actinosiphonate lamella (Fig. 6(A)), the spheruliticprismatic layer in the siphuncular ridges probably had a much denser structure than that in the layer of the connecting ring (Fig. 6(B)). The siphuncular ridges in Bathmoceras therefore have a similarly high resistance to diagenesis as do the actinosiphonate lamellae (Fig. 5(D)-(G)). The original porosity in the spherulitic-prismatic layer cannot be reconstructed in detail, because the original aragonitic crystallites probably are covered by a layer of small calcium phosphate crystals that were precipitated diagenetically (Mutvei 2011, fig. 7D).

In the specimen of Bathmoceras sp. (Holm 1899), the siphuncular ridges are structurally best preserved. Each ridge has a central dark line that may have been a central plate of chitinous material (Figs. 4(G), 5(A),(B)). This plate probably was secreted first and then was covered by the spheruliticprismatic layer. In the specimen of the oncocerid nautiloid Octamerella, each actinosiphonate lamella has a central plate (Fig. 5(G)) that is composed of calcareous crystals and covered by the spherulitic-prismatic layer of the actinosiphonate lamella (Mutvei 2011, figs. 1, 2, 3; 2013, fig. 9).

Gerontic endosiphuncular deposit. A calcareous endosiphuncular deposit appears in about the $18^{\text {th }}$ chamber behind the body chamber where it forms a thin layer on the dorsal siphuncular side (Fig. 4(B)). As in the specimen of Bathmoceras sp. (Fig. 4 (E)), this deposit in $B$. holmi probably originally was composed of thin calcareous lamellae, separated by narrow interspaces. During diagenesis, these lamellae probably were transformed into a continuous layer of calcite (Fig. 4(B)).

Distribution. The genus Bathmoceras had an exceptionally wide palaeogeographic distribution (Chen \& Teichert 1987; Kröger 2013). This was probably benefited by the improved function of the siphuncule.

\section{Function of the siphuncle in Bathmoceras}

Because the growth zone of the siphuncular ridges comprised about seven of the latest formed chambers (growth zone, Fig. 2 (A)), these chambers remained filled with cameral liquid. The removal of the cameral liquid probably began about the $8^{\text {th }}$ chamber where the siphuncular ridge had reached its full size (pumping zone, Fig. 2(A)). Simultaneously with the above processes, at the $17^{\mathrm{th}}-18^{\text {th }}$ chamber behind the body chamber, the siphuncular epithelium regained its secretory function and began to secrete the solid endosiphuncular deposit that prevented the transport of the cameral liquid through the connecting rings (gerontic endosiphuncular deposit, Fig. 2(A)). This deposit is best preserved in the specimen of Bathmoceras sp. (Holm 1899) where it consists of calcareous lamellae (Fig. 4 (E)). Consequently, the siphuncular cord could perform its osmotic pumping function only in about the 10 chambers that were situated between the end of the growth zone of the siphuncular ridges and the beginning of the gerontic endosiphuncular deposit (pumping zone, Fig. 2(A)).

Due to the extremely oblique course of the siphuncular segments (Figs. 1(C),(D), 2(D) and 3(A)), the surface area of the connecting rings and siphuncular ridges increased considerably. A similar, oblique course of the siphuncular segments occurs in the late Cambrian plectronocerids from China (Mutvei et al. 2007). The siphuncular ridges with the dense spheruliticprismatic structure in Bathmoceras probably increased the mechanical strength of the siphuncular wall. They also contained a large volume of cameral liquid in the pore spaces. This probably improved the transport of the cameral liquid through the siphuncular wall and made the animal well adapted for vertical, probably diurnal, migrations.

In comparison with the extant Nautilus, most fossil nautiloids probably had a poor swimming capability. During nautiloid

Fig. 5. Bathmoceras sp. Specimen no. SGU 179. A. B. Transverse section of the siphuncle to show two ridges with a central plate, $\times 30, \times 16$. C. Longitudinal section of the siphuncle through the lateral sides to show the ridges, $\times 6.0$. Octamerella cf. pugil. D. Specimen no. Mo. 150248 , longitudinal section of the adoral end of the siphuncle to show the actinosiphonate lamellae, $\times 12$. E. Specimen no. Mo. 152127, transverse section of the siphuncle to show the shape and arrangement of the actinosiphonate lamellae, $\times 15$. F. Actinosiphonate lamellae in the same section in higher magnification, $\times 30$. Octamerella sp. G. Specimen no. Mo. 5835, actinosiphonate lamellae in transverse section of the siphuncle to show central plates, $\times 45$. 

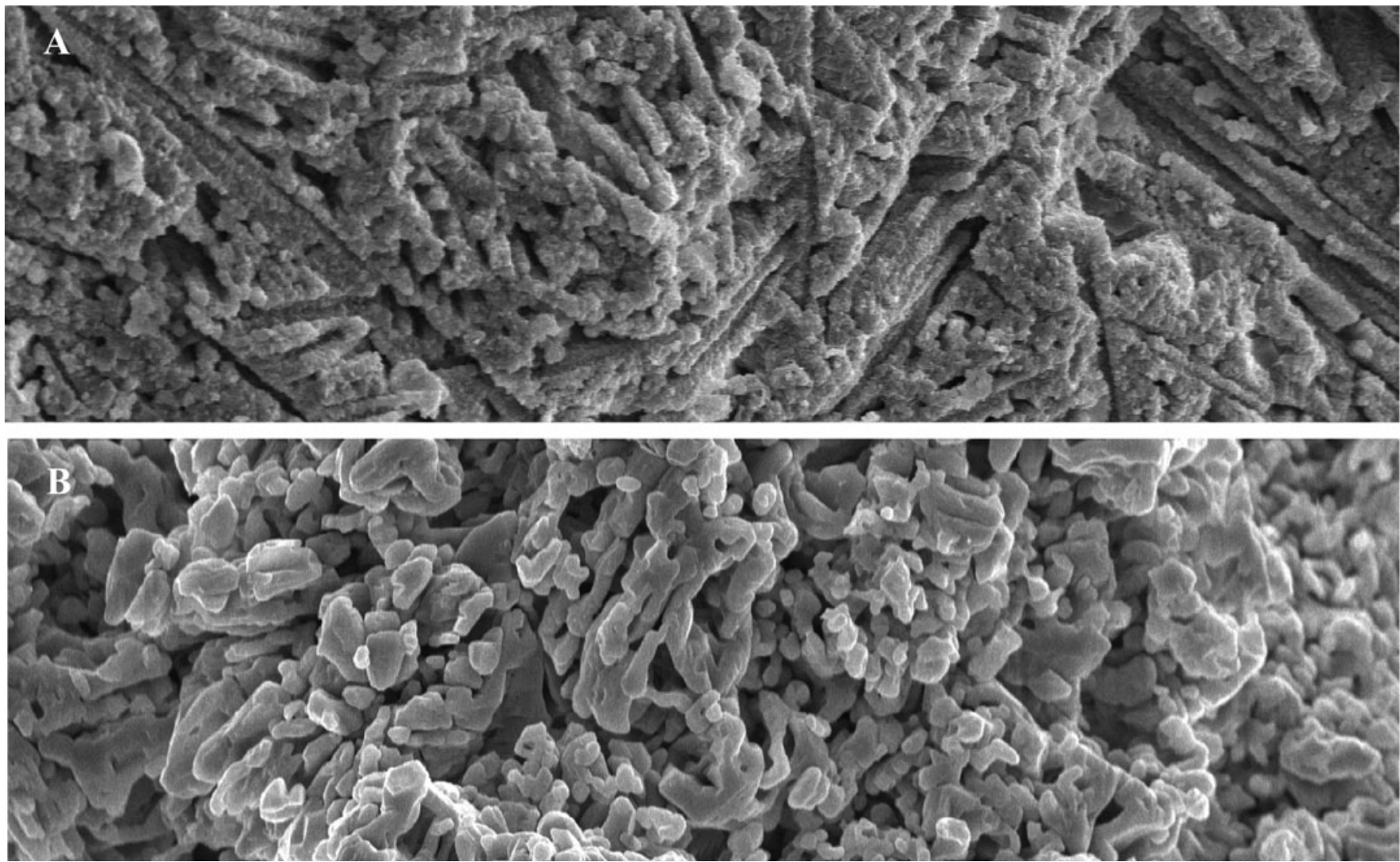

Fig. 6. SEM images. Octamerella sp. A. Specimen no. Mo. 5835, porous spherulitic-prismatic structure of the actinosiphonate lamellae. B. holmi. B. Specimen no. Mo. 151247, porous spherulitic-prismatic structure of the endosiphuncular ridge. Scale bars: $\mathbf{A}, \mathbf{B}=10 \mu \mathrm{m}$.

evolution, numerous types of the siphuncular structures, commonly very complicated, appeared (Mutvei 1996, 1998, 2002a, 2002b). This indicates that most fossil nautiloids were vertical migrants and that the siphuncular structure was important for buoyancy regulation in different marine environments.

\section{The siphuncular structure compared with that in other nautiloids}

According to Sweet (1964, p. K279), the siphuncles in several oncocerid nautiloids contain at least three types of the radial actinosiphonate lamellae. As pointed out above, in specimens of the Silurian oncocerid Octamerella (Mutvei 2011) such lamellae have several features in common with the siphuncular ridges in Bathmoceras. Both have connecting rings of the nautilus-type. The siphuncular ridges in Bathmoceras have a dense, spherulitic-prismatic structure similar to that seen in the actinosiphonate lamellae in Octamerella (Fig. 6 (A),(B); Mutvei 2011, figs. 6, 7 A-D)), and these dense structures therefore probably were resistant against diagenesis. The actinosiphonate lamellae in Octamerella and siphuncular ridges in Bathmoceras were secreted in the adoral portion of the siphuncle (Fig. 5(D)) and they participated in the osmotic pumping function of the cameral liquid. However, each siphuncular ridge in Bathmoceras was secreted on the inner surface of the connecting ring (Fig. 2(E)), whereas the actinosiphonate lamellae in Octamer- ella were secreted on the inner siphuncular surface along long axis of the siphuncle (Fig. 5(D)).

Flower (1957) regarded the siphuncular ridges in specimens of Bathmoceras as homologues with the endosiphuncular annuli in actinocerids. This interpretation was refuted by Teichert (1964) who pointed out that the siphuncular ridges are attached to the inner surface of the connecting rings, whereas the annuli in the actinocerids are separated from the connecting rings by a narrow cavity called the perispatium. However, the siphuncular ridges and the annuli have different ultrastructures, positions and, apparently, functions. (1) The ridges in Bathmoceras have a porous spherulitic-prismatic structure, whereas the annuli in actinocerids have a solid calcareous structure; (2) the ridges were secreted in the adoral portion of the phragmocone, whereas the annuli were secreted in the adapical region of the phragmocone; (3) the ridges participated in the regulation of the volume of the cameral liquid, whereas the annuli did not contribute to this regulation. Notably, the structure and the position of the annuli in the actinocerids correspond to the gerontic endosiphuncular deposit in Bathmoceras.

Acknowledgements - I express my gratitude to Dr R. H. Mapes, Ohio University, Athens, to Dr C. Klug, Paläontologisches Institut und Museum, Zürich, to Dr R.A. Davis, Mount St Joseph University, Cincinnati, Ohio and to an anonymous reviewer for valuable constructive Joseph Univicism.

Disclosure statement

No potential conflict of interest was reported by the author. 


\section{References}

Angelin, N.P. \& Lindström, G., 1880: Fragmenta Silurica o dono Caroli Henrici Wegelin. Samson \& Wallin, Holmiae, Stockholm, 60 p.

Barrande, J., 1865: Systeme Silurien du centre de la Bohême, Premiére Partie, Recherches paléontologiques, vol 1 Classe des Mollusques, Ordre des Céphalopodes. Published by Author, Prague, Paris.

Chen, J.Y. \& Teichert, C., 1987: The Ordovician cephalopod suborder Cyrtocerinina (Order Ellesmerocerida). Paleontologia Cathayana 3 , $145-229$.

Cichowolski, M., Waisfeld, B.G., Vaccari, N.E. \& Marengo, L., 2014: The nautiloid family Eothinoceratidae from the Florian of the Central Andean Basin (NW Argentina and South Bolivia). Geological Journal, doi:10.1002/gj. 2595.

Evans, D.E. \& King, A.H., 1990: The affinities of early oncocerid nautiloids from the Lower Ordovician of Spitsbergen and Sweden. Palaeontology 33, $623-630$.

Flower, R.H., 1946: Ordovician cephalopods from the Cinncinati Region, Part 1. Bulletins of American Paleontology 29, 556.

Flower, R.H., 1957: Studies of the Actinoceratida. New Mexico Institute of Mining and Technology Memoire 2, $100 \mathrm{p}$.

Flower, R.H., 1964: The nautiloid order Ellesmeroceratida (Cephalopoda). New Mexico Institute of Mining and Technology Memoire 12, 234.

Gill, T., 1871: Arrangement of the families of the Mollusca. Smithsonian Miscellaneous Collections 227, 49.

Hewitt, R.A. \& Stait, B., 1985: Phosphatic connecting rings and ecology of an Ordovician ellesmerocerid nautiloid. Alcheringa: An Australasian Journal of Palaeontology 9 (3), 229-243. doi:10.1080/03115518508618970.

Holm, G., 1899: Paleontologiska notiser: om Bathmoceras. Geologiska Föreningens $i$ Stockholm Förhandlingar 21, 271-305.

Jaanusson, V. \& Mutvei, H., 1982: Ordovician of Öland. IV International Symposium on the Ordovician System, Oslo 1982. Guide to Excursion 3, 23 p. 378 .

Kröger, B., 2004: Revision of Middle Ordovician orthoceratacean nautiloids from Baltoscandia. Acta Palaeontologica Polonica 49, 57-74.

Kröger, B., 2006: Early growth-stages and classification of orthoceridan Cephalopods of the Darriwillian (Middle Ordovician) of Baltoscandia. Lethaia 39, 129-139.

Kröger, B., 2012: The Vaginaten: the dominant cepahlopods of the Baltoscandian Mid Ordovician endocerid limestone. GFF 134, 115-132.

Kröger, B., 2013: Cambrian-Ordovician cephalopod palaeogeography and diversity. In T. Cervais \& D.A.T. Harper (eds.): Early Palaeozoic Biogeography and Palaeogegraphy, 428-429. The Geological Society of London, London.

Kröger, B. \& Mutvei, H., 2005: Nautiloids with multiple paired muscle scars from Lower-Middle Ordovician of Baltoscandia. Palaeontology 48, 781-791.

Kröger, B. \& Landing, E., 2008: Onset of the Ordovician cephalopod radiation evidence from the Rochdale Formation (middle Early Ordovician, Stairsian) in eastern New York. Geological Magazine 145, 490-520.

Kröger, B., Servais, T. \& Zhang, Y., 2009a: The origin and initial rise of pelagic cephalopods in the Ordovician. PLOS ONE 4 (9), 1-13.

Kröger, B., Zhang, Y. \& Isakar, M., 2009b: Discosorids and Oncocerids (Cephalopoda) of the Middle Ordovician Kunda and Aseri Regional Stages of Baltoscandia and the early evolution of these groups. Geobios 42, 273-292.
Mutvei, H., 1996: Characterization of actinoceratoid cephalopods by their siphuncular structure. Lethaia 29 (4), 339-348. doi:10.1111/j.1502-3931. 1996.tb01669.x.

Mutvei, H., 1998: Siphuncular structure in a Silurian narthecoceratid nautiloid cephalopod from the Island of Gotland. Geologiska Föreningens i Stockholm Förhandlingar 120, 375-378.

Mutvei, H., 2002a: Nautiloid systematics based on siphuncular structure and position of muscle scars. Abhandlungen der geologischen Bundesanstalt 57, 379-392.

Mutvei, H., 2002b: Connecting ring structure and its significance for classification of the orthoceratid cephalopods. Palaeontologica Polonica 47, $157-168$.

Mutvei, H., 2011: Silurian oncocerid Octamerella (cephalopoda) from Gotland, Sweden. GFF 133 (3-4), 125-133. doi:10.1080/11035897.2011.614956.

Mutvei, H., 2012: Siphuncular structure in Silurian discosorid and ascocerid nautiloids (Cephalopoda) from Gotland, Sweden: implications for interpretation of mode of life and phylogeny. GFF 134 (1), 27-37. doi:10.1080/ 11035897.2012 .654507

Mutvei, H., 2013: Characterization of nautiloid orders Ellesmerocerida, Oncocerida, Tarphycerida, Discosorida and Ascocerida: new superorder Multiceratoidea. GFF 135 (2), 171-183. doi:10.1080/11035897.2013. 801034.

Mutvei, H. \& Stumbur, H., 1971: Remarks on the Genus Pictetoceras (Cephalopoda: Ellesmerocerida). Bulletin of the Geological Institutions of the University of Uppsala NS 2, 117-122.

Mutvei, H. \& Dunca, E., 2011: Siphuncular structure in the orders Tarphycerida and Barrandeocerida (Cephalopoda: Nautiloidea). Palaeontology 54 (3), 705-710. doi:10.1111/j.1475-4983.2011.01041.x.

Mutvei, H. Zhang, Y.B. \& Dunca, E., 2007: Late Cambrian plectronocerid nautiloids and their role in cephalopod evolution. Palaeontology 50 (6), 1327-1333. doi:10.1111/j.1475-4983.2007.00708.x.

Mutvei, H., Dunca, E. \& Weitschat, W., 2010: Siphuncular structure in the Recent Nautilus, compared with that in Mesozoic nautilids and ammonoids from Madagascar. GFF 132 (3-4), 161-166. doi:10.1080/11035897.2010. 510204 .

Nielsen, S.N., Bandel, K. \& Kröger, B., 2009: Palaeobiogeographical provenance, taphonomy, and mode of life of Aturia cubaensis (Cephalopoda, Nautiloidea) from Cainozoic deposits of Chile. Geobios 42 (1), 73-88. doi:10. 1016/j.geobios.2008.07.006

Niko, S. \& Sone, M., 2014: Actinocerid cephalopods from the Ordovician of Myanmar, and their paleobiogeographic implications for northern Gondwana. Paleontological Research 18 (2), 94-103. doi:10.2517/2014PR010.

Stumbur, H. \& Mutvei, H., 1983: A new Middle Ordovician torticonic nautiloid. Geologiska Föreningens i Stockholm Förhandlingar 105, 43-47.

Sweet, W.C., 1964: Nautiloidea-Oncocerida. K277-K319. In R.C. Moore (ed.): Treatise on invertebrate paleontology, Part K, Mollusca 3, Cephalopoda. The Geological Society of America, Boulder, and The University of Kansas Press, Lawrence, $519 \mathrm{p}$.

Teichert, C., 1964: Actinoceratoidea. K190-K216. In R.C. Moore (ed.): Treatise on invertebrate paleontology, Part $K$, Mollusca 3, Cephalopoda. The Geological Society of America, Boulder, and The University of Kansas Press, Lawrence, $519 \mathrm{p}$.

Ulrich, E.O., Miller, A.K. \& Unklesbay, A.G., 1944: Ozarkian and Canadian cephalopods. Part III. Longicones and Summary. Geological Society of America Special papers 58, 1-226. 